\title{
Monitoring of Dung Beetle (Scarabaeidae and Geotrupidae) Activity Along Maryland's Coastal Plain
}

Author(s): Patrick Simons, Michael Molina, Mallory A. Hagadorn and Dana L. Price

Source: Northeastern Naturalist, 25(1):87-100.

Published By: Eagle Hill Institute

https://doi.org/10.1656/045.025.0108

URL: http://www.bioone.org/doi/full/10.1656/045.025.0108

BioOne (www.bioone.org) is a nonprofit, online aggregation of core research in the biological, ecological, and environmental sciences. BioOne provides a sustainable online platform for over 170 journals and books published by nonprofit societies, associations, museums, institutions, and presses.

Your use of this PDF, the BioOne Web site, and all posted and associated content indicates your acceptance of BioOne's Terms of Use, available at www.bioone.org/page/ terms of use.

Usage of BioOne content is strictly limited to personal, educational, and non-commercial use. Commercial inquiries or rights and permissions requests should be directed to the individual publisher as copyright holder. 


\title{
Monitoring of Dung Beetle (Scarabaeidae and Geotrupidae) Activity Along Maryland's Coastal Plain
}

\author{
Patrick Simons ${ }^{1}$, Michael Molina ${ }^{1}$, Mallory A. Hagadorn ${ }^{2}$, and Dana L. Price ${ }^{1, *}$
}

\begin{abstract}
Our understanding of how human activities impact insect communities is limited. Dung beetles, well known for the ecosystem services they provide, are faced with many conservation threats, particularly from deforestation and agriculture. Here we used 200-m transects and human-dung-baited pitfall traps to examine dung beetle populations in 7 forests of Maryland's Coastal Plain. We set traps once a month, from May 2014 to April 2015, to determine species presence, abundance, range, and seasonality. We collected 6463 individuals representing 22 species; Janes Island State Park (JISP) had the highest abundance (2705 individuals) and Martinak State Park (MSP) had the highest species richness (19 species). During summer 2015, we examined the succession of dung beetles attracted to bait in JISP and MSP. We set 10 traps once a month (May-August) in each site and collected beetles on days 1, 3, 5, 7, 14, and 21 without dung replacement. In JISP, Onthophagus hecate (Scooped Scarab) was abundant throughout each 21 -d period, and accounted for $68 \%$ of all beetles collected. In MSP, most specimens were collected by day 5 . Here we provide information for conservation of locally rare or uncommon species.
\end{abstract}

\section{Introduction}

The Atlantic Coastal Plain is the largest physiographic province in Maryland, with the Piedmont/Coastal Plain fall line crossing through the northeastern tip of the state (Edwards 1981). Maryland's Eastern Shore, east of the Chesapeake Bay and Elk River, consists of 9 counties, which make up 32\% of the state's land area. This region is characterized by a flat, low-lying landscape, with elevations usu-

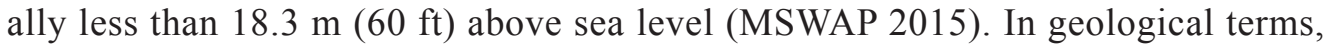
Maryland's Eastern Shore consists of unconsolidated sediments of gravel, sand, silt and clay, and represents the youngest region of the state (Edwards 1981). For 6000 years, the modern vegetation of the area changed very little, yet with the increase in human population in the 1800 s, people cut large swathes of forest to support shipbuilding, paper pulp, and iron manufacture, and increased agriculture (Brush 2008). By the early 1900 s, $60-80 \%$ of the Chesapeake Bay watershed was deforested and under cultivation (Brush and Hilgartner 2000). As the Great Depression swept the US, farms were abandoned, and human populations shifted to urban areas (Brush 2008, Kays 1995). Former agricultural lands reverted to Pinus (pine) and hardwood forests, which comprises most of the Eastern Shore's modern forest cover (Kays 1995). Area of impervious surfaces increased and forests became fragmented as urbanization continued (Brush 2008). Today, forest cover varies from $35 \%$ to $51 \%$;

\footnotetext{
${ }^{1}$ Department of Biological Sciences, Salisbury University, Salisbury, MD 21801. ${ }^{2}$ Department of Biology, Utah State University, Logan, UT 84322. * Corresponding author dlprice@salisbury.edu.
}

Manuscript Editor: Ralph Grundel 
forests are dominated by Quercus (oak)-Carya (hickory) and oak-pine, the latter prevailing in the southernmost counties (Kays 1995).

Through the urbanization process, many of the large-mammal species that historically inhabited this area became regionally extinct. Puma concolor L. (Cougar), Ursus americanus Pallas (American Black Bear), Canis lupus L. (Grey Wolf), and possibly Bison bison L. (Bison) formerly occurred on Maryland's Eastern Shore, but could not persist following human population growth and development (Scott 1991, Sipple 1994). Today, the large terrestrial mammal fauna is limited to Odocoileus virginianus Zimmerman (White-tailed Deer), Cervus nippon Temminck (Sika Deer), Procyon lotor L. (Raccoon), Canis latrans Say (Coyote), Vulpes vulpes L. (Red Fox), and Urocyon cinereoargenteus Schreber (Gray Fox). Many of the habitats where these animals thrive are the same as those valued for recreation and other human activities (Brofman 2015). We need to assess the major threats to wildlife in this region and determine how to maintain animal populations in an ecological manner, but one that also supports recreational activities and other human interests (MSWAP 2015).

Dung beetles (Coleoptera: Scarabaeidae and Geotrupidae) are extremely beneficial in forest habitats where their feeding and burial of dung promotes nutrient cycling and maintenance of key ecosystem processes (Nichols et al. 2008, 2009). These beetles are also known to be excellent indicators of biodiversity (Gardner et al. 2008; Larsen 2007, Larsen 2011, Spector 2006) and environmental health (Davis et al. 2001, Feer and Hingrat 2005, McGeoch et al. 2002, Nichols and Gardner 2011). Thus, regional decline in mammal fauna can disrupt the diversity and abundance of dung beetle communities, with significant short- and long-term implications (Nichols et al. 2009). In many ecosystems, dung is an ephemeral resource, which makes competition for this microhabitat intense (Hanski and Cambefort 1991).

Assessment of environmental threats to dung beetle biodiversity and establishment of land-management practices for conservation of these communities is of critical importance. Here we examine dung-beetle activity in 7 forests along 150 $\mathrm{km}$ of Maryland's Eastern shore. With the exception of dung beetles collected from cattle farms (M.A. Hagadorn et al., unpubl. data), very little is known about Maryland's dung beetles (Price et al. 2012, Rentz and Price 2016). Herein,we provide data on diversity and abundance, seasonal activity, and range of forest-dwelling dung beetles, and examine the succession of these beetles attracted to a limited food resource. We assessed dung beetle communities, as a whole, to better understand the unique ecosystem in which they live and provide data to suggest that several species are locally rare or uncommon.

\section{Field-site Descriptions}

We sampled dung beetles in 7 forests along Maryland's Eastern Shore (Fig. 1)— Sassafras Natural Resource Management Area (SNRMA), Tuckahoe State Park TSP), Martinak State Park (MSP), Seth Demonstration Forest (SDF), Henson Scout Reserve (HSR), Showell Conservation Easement (SCE), and Janes Island State Park (JISP) (Table 1). We obtained permits for collection of beetles in the 5 parks that are 
owned and managed by the Maryland Department of Natural Resources (MDNR). We also obtained permission for collections in the Henson Scout Reservation and Showell Conservation Easement (owned by Maryland Coastal Bays Program).

\section{Methods}

\section{Diversity collections}

In order to examine dung beetle species richness and abundance, we used 200-m linear transects, with human-dung-baited pitfall traps (Larsen and Forsyth 2005), set every $50 \mathrm{~m}$ ( 5 total for each site). Human dung is among the most attractive baits to most species of coprophagous beetles (Howden and Nealis 1975) and is a readily available resource. Traps consisted of a 2.4-L (2.5-qt) plastic container (16 $\mathrm{cm}$ diameter, $15 \mathrm{~cm}$ depth) buried in the soil, flush to the rim. We hung mixed human dung, wrapped in cheesecloth and tied with biodegradable twine, from mesh chicken wire placed over the bucket.. We placed a $20 \mathrm{~cm}$ x $20 \mathrm{~cm}$ plywood tile at a $45^{\circ}$ angle above the trap to prevent rainwater flooding. We added a small amount of water and table salt to the bottom of each bucket to preserve the specimens until collection. We baited the traps once a month (May 2014-April 2015) for a 7-d period. We placed all collected beetles in $75 \%$ ethanol and returned to the lab for sorting and identification. We calculated estimated species richness (Chao1, ICE, and ACE richness metrics) in EstimateS version 9.1.0 software (Colwell 2013). We created species-accumulation curves to illustrate the rate at which new species were sampled and examined rarefaction curves to compare species richness among the 7 forests (Gotelli and Colwell 2001). We examined species diversity using the Shannon exponential mean $\left(\mathrm{e}^{\mathrm{H}}\right)$ and Simpson's index (1/D).

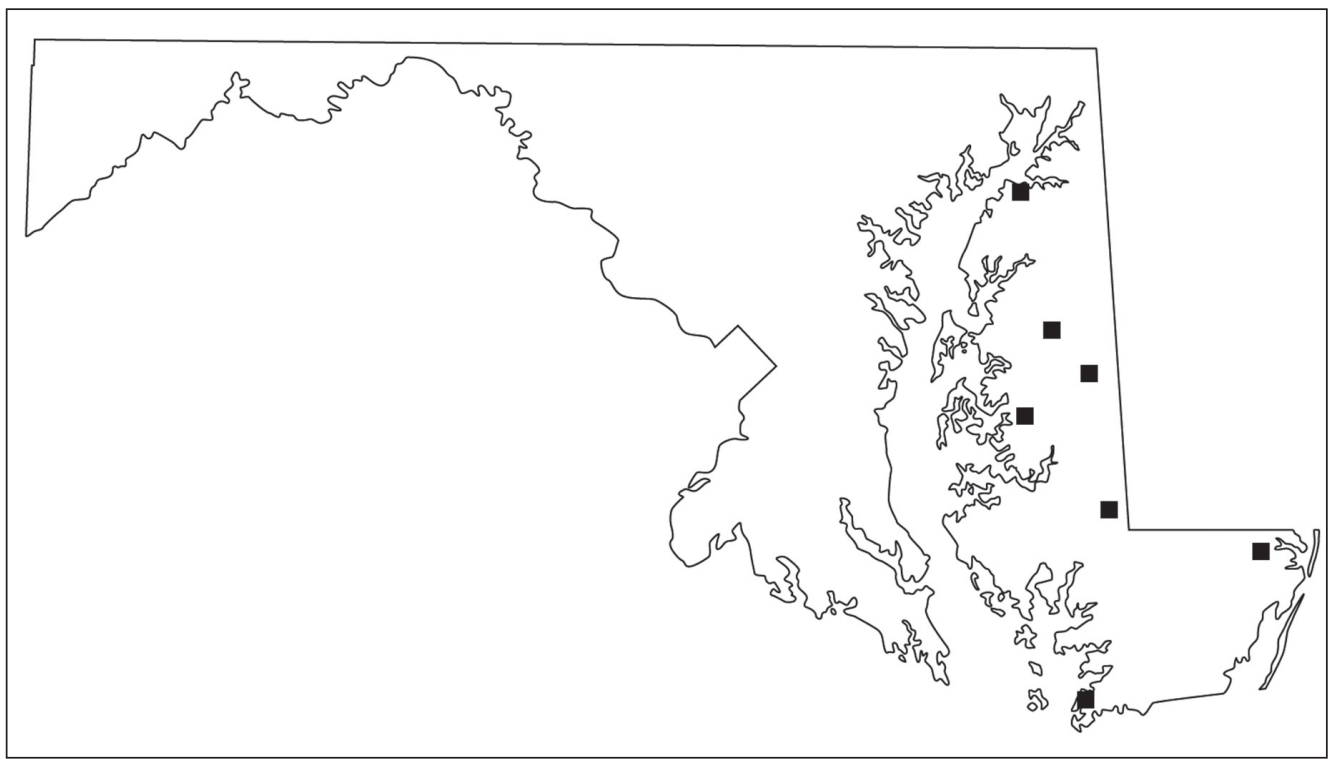

Figure 1. Location of 7 forests along Maryland's Coastal Plain region. Site locations are listed north to south in Table 1. 
P. Simons, M.Molina, M.A. Hagadorn, and D.L. Price

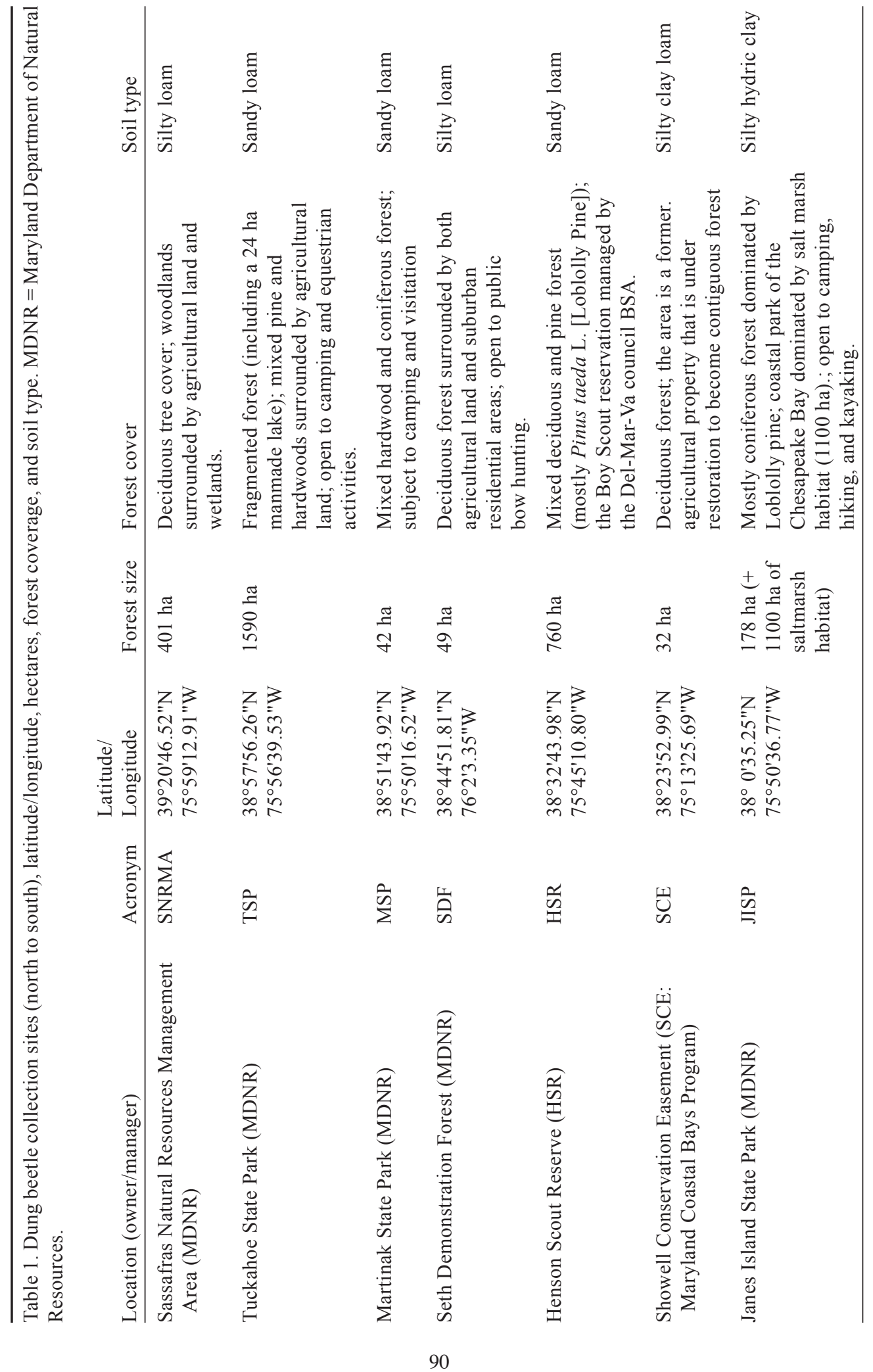




\section{Succession}

To determine the succession of dung beetles attracted to dung bait, we followed methods similar to Sabu et al. (2007) and Rentz and Price (2016) to collect beetles. This method allowed us to determine when beetles were attracted to the bait, and if possible, to capture additional species with an extended collection period. We set 10 pitfall traps (as described above) at 2 sites: MSF and JISP (Table 1). We randomly placed traps at least $50 \mathrm{~m}$ apart to avoid interference with other traps (Larsen and Forsyth 2005). We baited the traps with $50 \mathrm{~g}$ of mixed human dung once a month (May-August 2015) and collected beetles after days 1, $3,5,7,14$, and 21 days without replacement of bait. We preserved specimens in $75 \%$ ethanol for later sorting and identification. We pinned/pointed specimens of rare species and placed them in the DLP Entomological Collection at Salisbury University, Salisbury, MD.

\section{Results}

\section{Species diversity and richness}

Dung-beetle species richness was highest in MSP (19 species and 1218 individuals collected) and lowest in TSP (10 species and 203 individuals collected) (Tables 2, 3). JISP had low species richness (11), yet the highest abundance of all sites: 2705 individuals collected (Tables 2, 3). The estimated species richness for the sites varied from 11 to 22 species (Table 2). Sample-based species-accumulation curves demonstrate that we collected $80 \%$ of the species after just 8 samples (Fig. 2). All sites need further sampling, with the exception of JISP which reached an asymptote by sample 10 (Fig. 2); all richness indices for JISP corroborate these findings (Table 2). Rarefaction curves suggest there is high variation in community structure among the different forests (Fig. 3). Both MSP and SNMRA had high species-richness and low density; JISP had extremely high density and was omitted from the rarefaction analysis (Fig. 3). Species diversity $\left(\mathrm{e}^{\mathrm{H}}\right.$ and 1/D) was similar among all sites, varying from 2.71 to 5.61 (Table 3).

Table 2. Species richness, abundance, and diversity of dung beetles collected from 7 forests of Maryland's Atlantic Coastal Plain. ICE = incidence-based coverage estimator of species richness and ACE $=$ abundance-based coverage estimator of species richness. See Table 1 for location acronyms.

\begin{tabular}{lrrrrrrr} 
& \multicolumn{7}{c}{ Location } \\
\cline { 2 - 7 } & SNRMA & TSP & MSP & SDF & HSR & SCE & JISP \\
\hline $\begin{array}{l}\text { Species richness } \\
\text { Abundance }\end{array}$ & 11 & 10 & 19 & 13 & 12 & 12 & 11 \\
Estimated species richness & 308 & 203 & 1218 & 494 & 518 & 1017 & 2705 \\
$\quad$ Chao 1 & 19.00 & 10.66 & 21.25 & 15.00 & 12.50 & 12.00 & 11.00 \\
$\quad$ ICE & 14.36 & 12.64 & 22.41 & 14.15 & 14.08 & 14.22 & 11.00 \\
$\quad$ ACE & 15.82 & 11.90 & 21.57 & 14.30 & 12.48 & 12.30 & 11.00 \\
Species diversity & & & & & & & \\
$\quad$ Shannon exponential mean (e $\left.\mathrm{e}^{\mathrm{H}}\right)$ & 3.47 & 4.93 & 5.61 & 4.34 & 5.29 & 4.53 & 4.72 \\
$\quad$ Simpson's index (1/D) & 2.71 & 4.12 & 3.58 & 2.78 & 4.25 & 3.75 & 3.26 \\
\hline
\end{tabular}


We found the indigenous species Copris minutus (Small Black Dung Beetle), Geotrupes blackburnii (Blackburn's Earth Boring Beetle), and Onthophagus hecate (Scooped Scarab) at all 7 sites; these were the 3 most abundant species overall, with 816, 2048, and 1966 individuals collected, respectively. We also collected another indigenous species, Onthophagus pennsylvanicus, in all 7 forests, but in low numbers, with the exception of JISP (345 individuals). Species captured in abundance in only 1 or 2 forests include Irrasinus stupidus (MSP and HSR), Canthon viridis (SDF and TSP), and Onthophagus concinnus (MSP and SCE). Geotrupes splendidulus was only collected in SDF. We collected 1 specimen of Copris fricator from SNRMA, the northernmost forest, and 2 specimens ( 1 in TSP and 1 in MSP) of Onthophagus subaneus. Both $C$. fricator and O. subaneus had previously only been reported from counties west of the Chesapeake Bay (Staines 1984).

Seasonality of beetles was similar in all 7 forests, though not all species were present in all forests (Tables 4). In general, Geotrupes blackburnii was most abundant March-May, and again from October-December (Table 4). Abundance was highest for Canthon chalcites, Onthophagus hecate, and O. pennsylvanicus during May-August, for G. egeriei (Eger's Earth Boring Beetle) in July-September, and for Copris minutus during August-November (Table 4).

Table 3. Dung beetles collected from 7 forests of Maryland's Atlantic Coastal Plain. See Table 1 for location acronyms.

\begin{tabular}{|c|c|c|c|c|c|c|c|c|}
\hline \multirow[b]{2}{*}{ Family/species } & \multicolumn{7}{|c|}{ Location } & \multirow[b]{2}{*}{ Total } \\
\hline & SNRMA & TSP & MSP & SDF & HSR & SCE & JISP & \\
\hline \multicolumn{9}{|l|}{ Scarabaeidae (Aphodiinae) } \\
\hline Alloblackburneus rubeolus (Palisot de Beauvois) & ) & - & 1 & - & - & - & - & \\
\hline Blackburneus stercorsus (Melsheimer) & 3 & - & 6 & 1 & - & 7 & 14 & 31 \\
\hline Irrasinus stupidus (Horn) & - & - & 38 & - & 4 & - & - & 42 \\
\hline Oscarinus rusicola (Melsheimer) & 1 & - & 11 & 2 & 8 & 6 & 61 & 89 \\
\hline Pseudagolius bicolor (Say) & 4 & - & 43 & 7 & 3 & 7 & 50 & 114 \\
\hline \multicolumn{9}{|l|}{ Scarabaeidae (Scarabaeinae) } \\
\hline Ateuchus histeroides (Weber) & 1 & - & 1 & - & - & - & - & \\
\hline Canthon chalcites (Handel & - & - & 3 & - & 62 & 88 & 118 & 271 \\
\hline Canthon viridis (Palisot de Beauvois) & - & 2 & - & 24 & - & - & - & 26 \\
\hline Copris fricator (Fabricius) & 1 & - & - & - & - & - & - & \\
\hline Copris minutus (Drury) & 21 & 35 & 126 & 37 & 114 & 220 & 263 & 816 \\
\hline Onthophagus concinnus Laporte & - & - & 46 & - & - & 2 & - & 48 \\
\hline Onthophagus hecate (Panzer) & 129 & 56 & 9 & 89 & 33 & 295 & 1355 & 1966 \\
\hline Onthophagus orpheus (Panzer) & 12 & 29 & 2 & 3 & - & 4 & - & 50 \\
\hline Onthophagus pennsylvanicus Harold & 1 & 2 & 23 & 3 & 1 & 6 & 345 & 381 \\
\hline Onthophagus striatulus (Palisot de Beauvois) & 2 & 6 & 2 & 26 & 2 & - & 32 & 70 \\
\hline Onthophagus subaeneus (Palisot de Beauvois) & - & 1 & 1 & - & - & - & - & \\
\hline Onthophagus taurus (Schreber) & - & - & 3 & 4 & - & 1 & 2 & 10 \\
\hline Onthophagus tuberculifrons Harold & - & 1 & 238 & 1 & 3 & - & - & 243 \\
\hline Phanaeus vindex Macleay (Rainbow Scarab) & - & - & 8 & - & 3 & 18 & 22 & 51 \\
\hline \multicolumn{9}{|l|}{ Geotrupidae } \\
\hline Geotrupes blackburnii (Fabricius & 133 & 69 & 573 & 277 & 190 & 363 & 443 & 2048 \\
\hline Geotrupes egeriei Germar & - & 2 & 84 & - & 95 & - & - & 181 \\
\hline Geotrupes splendidus (Fabricius) & - & - & - & 20 & - & - & - & \\
\hline
\end{tabular}




\section{Succession}

To determine the degree of attraction to a food resource over time, we examined the succession of beetles attracted to human-dung-baited pitfall traps during a 21-d collection period (Hanski 1980, Menéndez and Gutiérrez 1999). During May to August 2015, we collected 3777 beetle specimens, 18 species (516 individuals) from MSP (Table 5) and 9 (3261 individuals) from JISP (Table 6). In MSP, we collected $88 \%$ of the beetles by day 7 (Table 5). The 2 most abundant species in MSP were Geotrupes blackburnii, and G. egerieri. According to our seasonality data (Table 4), G. backburnii is most abundant May and June, while G. egerieri is abundant during July and August (Table 4). Copris minutus, Onthophagus hecate, $O$. pennsylvanicus, $O$. striatulus, and $O$. tuberculifrons were each sampled throughout the entire 21-d collection period, suggesting there is considerable competition for resources in this forest.

At JISP, we collected $70 \%$ of the individuals by day 7 (Table 6). As in the diversity study, $O$. hecate was the most abundant species accounting for $68 \%(2212$

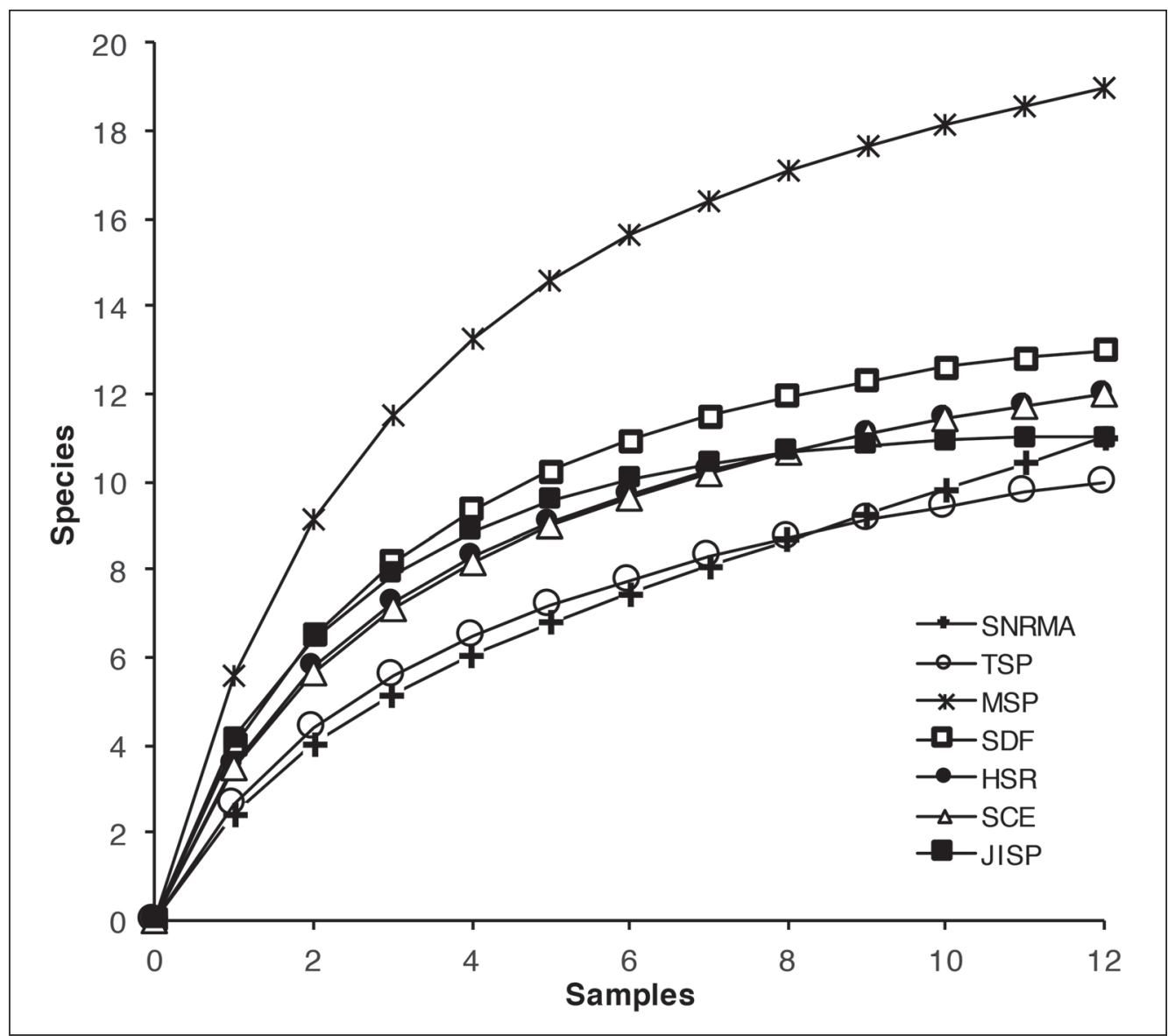

Figure 2. Species-accumulation curves for dung beetles collected May 2014-April 2015, from 7 forests along Maryland's Coastal Plain region. Locations are provided in the legend, north to south. See Table 1 for location acronyms. 
of 3261) of the specimens collected. Oscarinus rusicola (Aphodiinae) was the only species at JISP that was more abundant after day 7, with 147 of 217 specimens collected on days 14 and 21 (Table 6). No new species were found at MSP or JISP.

\section{Discussion}

\section{Species diversity}

MSP and TSP, located less than $15 \mathrm{~km}$ from one another, are both vegetated by hardwoods and mixed pines on sandy loam soils and used for camping and hiking activities. Thus, it is interesting that MSP had the highest species richness and TSP the lowest. The MSP forest site was part of a nearly contiguous 42-ha forest, bordered by the Choptank River and Watts Creek. In contrast, TSP is the largest park we investigated (1590 ha), but it is highly fragmented by agriculture, a factor that may contribute to low species richness and abundance.

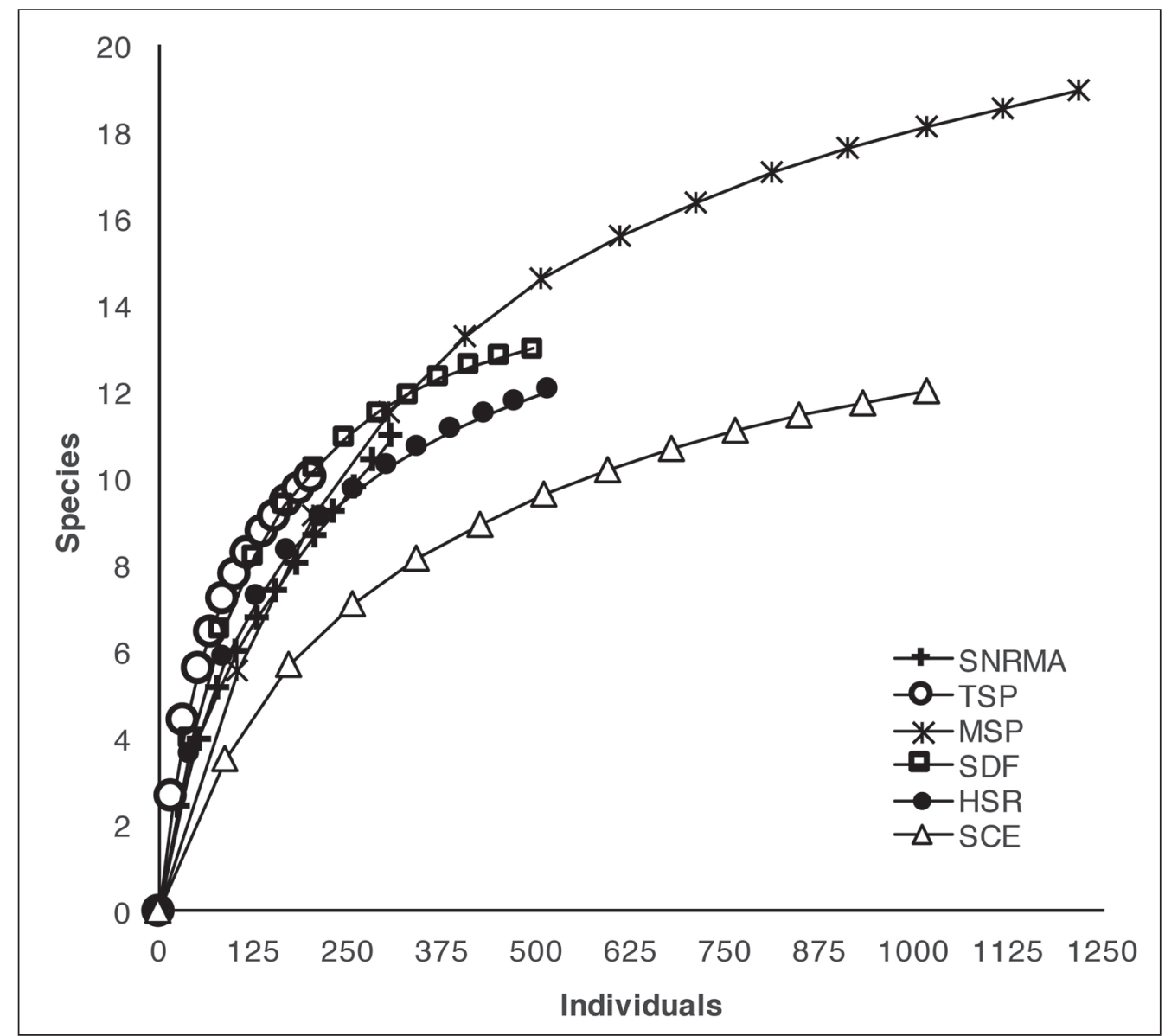

Figure 3. Sample-based rarefaction curves for dung beetles collected May 2014-April 2015, from 6 forests along Maryland's Coastal Plain region. We omitted Janes Island State Park here because the abundance of beetles collected was at least twice that of all other forests, and an asymptote was demonstrated after 10 samples (see Fig. 2). Locations are provided in the legend, north to south. See Table 1 for location acronyms. 
JISP, located in the southernmost region of Maryland, is made up of 2 distinct regions: (1) a 178-ha area including campsites and forested landscape bordered by agriculture; and (2) the largest portion that is only accessible by boat (MDNR 2017). Humans have harvested resources at this site for thousands of years, yet birds, fish and many other salt-marsh dwellers still flourish on the island (MDNR 2017). What is of most interest here is that we collected 2705 specimens from this park, more than twice that of MSP, which had the second highest abundance. Onthophagus hecate accounted for $69 \%$ of the individuals collected in this forest. This beetle is a generalist species that feeds on a wide variety of food resources, and is broadly distributed throughout the US (Price et al. 2012, Ratcliffe and Paulsen 2008, Staines 1984). In general, we believe this species is usually abundant in the Northeast where few other species are able to compete (Price 2004, Rentz and Price 2016, the present study). Competition from the wide diversity of other species found at MSP might explain why only 9 specimens were collected in MSP. Furthermore, JISP is the only site that was regularly inundated with brackish water. Salinity tolerance may be a factor inhibiting colonization by other species. Onthophagus hecate in particular has been shown to have a high tolerance for hypoxic conditions

Table 4. Seasonality of dung beetles collected from 7 forests, from May 2014 to April 2015, along Maryland's Atlantic Coastal Plain.

\begin{tabular}{|c|c|c|c|c|c|c|c|c|c|c|c|c|}
\hline \multirow[b]{2}{*}{ Family/species } & \multicolumn{12}{|c|}{ Month } \\
\hline & Jan & Feb & Mar & Apr & May & Jun & Jul & Aug & Sep & Oct & Nov & Dec \\
\hline Scarabaeidae (Aphidiinae) & - & - & - & - & - & - & - & - & - & - & - & \\
\hline Alloblackburneus rubeolus & - & - & - & - & 1 & - & - & - & - & - & - & \\
\hline Blackburneus stercorsus & - & - & - & - & 4 & - & 6 & 6 & 15 & - & - & \\
\hline Irrasinus stupidus & - & - & 11 & 3 & - & - & - & - & - & 19 & 4 & 5 \\
\hline Oscarinus rusicola & - & - & - & - & - & - & 83 & 1 & 2 & 3 & - & \\
\hline Pseudagolius bicolor & - & - & - & - & - & - & - & - & 2 & 109 & 1 & 2 \\
\hline \multicolumn{13}{|l|}{ Scarabaeidae (Scarabaeinae) } \\
\hline Ateuchus histeroides & - & - & - & - & - & 1 & 1 & - & - & - & - & \\
\hline Canthon chalcites & - & - & - & - & 48 & 85 & 42 & 74 & 19 & 3 & - & \\
\hline Canthon viridis & - & - & - & 1 & - & 5 & 9 & 5 & 6 & - & - & \\
\hline Copris fricato & - & - & - & - & - & - & - & - & 1 & - & - & \\
\hline Copris minutu & - & - & 16 & 38 & 8 & 1 & 13 & 105 & 164 & 201 & 237 & 33 \\
\hline Onthophagus concinnus & - & - & - & 1 & 33 & - & 4 & 3 & 7 & - & - & \\
\hline O. hecate & - & - & - & 1 & 392 & 259 & 428 & 690 & 162 & 34 & - & \\
\hline O. orpheus & - & - & - & - & 7 & 21 & 8 & 5 & 8 & 1 & - & \\
\hline O. pennsylvanicus & - & - & - & - & 29 & 165 & 125 & 60 & 2 & - & - & \\
\hline O. striatulus & - & - & - & - & - & 44 & 2 & 20 & 4 & - & - & \\
\hline O. subaeneus & - & - & - & - & 1 & - & - & - & 1 & - & - & \\
\hline O. taurus & - & - & - & - & 1 & 2 & 3 & 3 & 1 & - & - & \\
\hline O. tuberculifrons & - & - & 6 & 2 & 114 & 12 & 6 & 1 & 72 & 30 & - & \\
\hline Phanaeus vindex & - & - & - & - & - & 10 & 1 & 19 & 21 & - & - & \\
\hline \multicolumn{13}{|l|}{ Geotrupidae } \\
\hline Geotrupes blackburn & 20 & - & 242 & 319 & 136 & 3 & - & - & 27 & 865 & 255 & 181 \\
\hline Geotru & - & - & 1 & - & 4 & 1 & 80 & 22 & 60 & 13 & - & \\
\hline Geotrupes splendidus & - & - & - & 1 & 5 & 1 & 8 & 5 & - & - & - & \\
\hline
\end{tabular}


(Whipple 2011), suggesting it may have a competitive advantage in low-lying, regularly flooded areas like this site.

\section{Species of concern}

We collected Ateuchus histeroides in SNRMA (1 specimen) and MSP (1 specimen from the diversity study and 3 specimens during the succession study). This species had been previously taken from a variety of food resources, including mammal dung, (Fincher et al. 1970, Nealis 1977, Ratcliffe and Paulsen 2008, Woodruff, 1973), from a Marmota monax L. (Woodchuck) burrow (Woodruff 1973), both vertebrate and invertebrate carrion (Payne and King 1969, Reed 1958, Walker 1957,

Table 5. Heterotrophic succession of dung beetles collected in human-dung-baited pitfall traps in Martinak State Park. Beetles were collected on days 1, 3, 5, 7, 14, and 21 without replacement of dung.

\begin{tabular}{lrrrrrrr} 
Species & Day 1 & Day 3 & Day 5 & Day 7 & Day 14 & Day 21 & Total \\
\hline Ataenius sp. & - & - & - & - & 2 & - & 2 \\
Ateuchus histeroides & - & 1 & - & - & 2 & - & 3 \\
Blackburneus sp. & - & - & 1 & - & - & - & 1 \\
Canthon chalcites & 2 & - & 1 & - & 1 & - & 4 \\
Copris minutus & 3 & 11 & 2 & 2 & 10 & 2 & 30 \\
Geotrupes blackburnii & 24 & 49 & 24 & 12 & 3 & - & 112 \\
Geotrupes egeriei & 27 & 101 & 10 & - & 2 & - & 140 \\
Geotrupes splendidus & - & 1 & - & - & - & - & 1 \\
Onthophagus concinnus & 14 & 8 & - & 2 & - & - & 24 \\
O. hecate & 8 & 5 & 2 & 2 & 3 & 1 & 21 \\
O. orpheus & 4 & - & 1 & - & 3 & 2 & 10 \\
O. pennsylvanicus & 34 & 21 & 11 & 1 & 5 & 1 & 73 \\
O. striatulus & 2 & 3 & 6 & 5 & 9 & 4 & 29 \\
O. subaeneus & 1 & - & - & - & - & - & 1 \\
O. taurus & 1 & 1 & - & - & - & - & 2 \\
O. tuberculifrons & 11 & 14 & 5 & 5 & 2 & 10 & 47 \\
Oscarinus rusicola & 2 & 4 & 5 & 2 & 1 & - & 14 \\
Phanaeus vindex & 1 & - & 1 & - & - & - & 2 \\
Total abundance & 134 & 219 & 69 & 31 & 43 & 20 & 516 \\
\hline
\end{tabular}

Table 6. Heterotrophic succession of dung beetles collected in human-dung-baited pitfall traps in Janes Island State Park. Beetles were collected on days 1, 3, 5, 7, 14, and 21 without replacement of dung.

\begin{tabular}{lrrrrrrr} 
Species & Day 1 & Day 3 & Day 5 & Day 7 & Day 14 & Day 21 & Total \\
\hline Blackburneus stercorsus & - & - & 2 & 1 & - & - & 3 \\
Canthon chalcites & 126 & 64 & 43 & 17 & 44 & 9 & 303 \\
Copris minutus & 1 & 8 & 4 & 2 & 21 & 4 & 40 \\
Geotrupes blackburnii & 42 & 50 & 34 & 16 & 3 & - & 145 \\
Onthophagus hecate & 751 & 397 & 229 & 148 & 420 & 267 & 2212 \\
O. pennsylvanicus & 119 & 51 & 27 & 1 & 24 & 4 & 226 \\
O. striatulus & 5 & 11 & 14 & 23 & 32 & 17 & 102 \\
Oscarinus rusicola & 12 & 10 & 24 & 24 & 105 & 42 & 217 \\
Phanaeus vindex & 2 & 6 & 3 & 1 & - & 1 & 13 \\
Total abundance & 1058 & 597 & 380 & 233 & 649 & 344 & 3261 \\
\hline
\end{tabular}


Woodruff 1973, Young 1984), rotting fungi (Woodruff 1973), and cantaloupebaited pitfall traps (Walker 1957). Young (2007) demonstrated that this species can survive and reproduce on a variety of resources. Our data confirms that A. histeroides is rare in this region.

We collected Canthon viridis in TSP and SDF. This species appears to replace C. chalcites in the middle shore. Canthon viridis has been reported from mammal and bird dung, fungi, and carrion (Blume 1981, Staines 1984), and prefers dense wooded areas (Staines 1984).

Copris fricator was previously reported from counties west of the Chesapeake Bay. Here we collected just 1 specimen in SNRMA, our northernmost forest.

We documented Geotrupes splendidus at SDF during the diversity study, and collected 1 individual from MSP during the succession study. SDF is part of the Chesapeake Forest Lands, which has a sustainable management plan intended to be a national model for sustainable forestry and ecosystem management on public lands (MDNR 2015). Geotrupes splendidus is reportedly attracted to a variety of food resources, including fungi, mammal dung, dead animals, and chicken feathers (Fincher et al. 1970, Howden 1955). Howden (1955) suggested fungi as the preferred food.

Our study found Onthophagus concinnus only in MSP and SCE, although a specimen was collected previously in TSP (D.L. Price, unpubl. data). Interestingly, this species occurs from New Jersey to Florida, but it is never common (Howden and Cartwright 1963). These authors suggest a possible explanation may be that $O$. concinnus is usually taken from the dung of small mammals, such as Mephitis mephitis (Schreber) (Skunk), Vulpes spp. and Urocyon spp. (foxes), (foxes), all dung sources that are not often used for sampling. Price et al. (2012) collected several individuals of this species in the Pocomoke State Forest of Southern Maryland, suggesting that it prefers sandy soils.

We collected Onthophagus orpheus in all but 2 of the 7 forests we studied (JISP and HSR). This species prefers old-growth forests (Price 2004), and thus, was found here in low numbers.

Onthophagus subaeneus was previously only reported west of the Chesapeake Bay. We collected just 2 specimens, one from TSP and the other MSP. This species has been taken from a variety of food resources, including fungi, dung, and carrion, and prefers moist woodlands (Staines 1984). In general, O. subaeneus is rarely in collections (Harpootlian 2001, Woodruff 1973).

\section{Conclusions}

Maryland's geographic diversity spans from mountains and valleys, to rolling hills, and coastal flatlands and beaches. Wildlife distribution and abundance in this Mid-Atlantic state is dependent upon and intricately connected to the ecological integrity and diversity of its habitats (MSWAP 2015). Thus, an understanding of why certain species occur along the Coastal Plain ecoregion leads to understanding threats and allows for development of conservation actions (MSWAP 2015).

While many invertebrate species are reportedly important players in the ecosystem, dung beetles are well known for their ecosystem functions and services 
they provide (Nichols et al. 2008). Here we provide documentation of rarity for several uncommon and/or rare dung beetle species that we think merit conservation. Our findings suggested that several species are generalists either in their food or habitat preferences, but that others prefer unknown resources and deserve further investigation.

\section{Acknowledgments}

We thank Stephen Kelly and David Ortiz for completing a pilot study prior to this research. We are grateful to the numerous park and forest managers for their permission to collect dung beetles in Maryland, including Ryan Haley (Maryland Department of Natural Resources), Dennis Smith (JISP), Roman Jesien (Maryland Coastal Bays Program), and John Ohler (MSP, TSP, and SNRMA). We appreciate Paul Skelley (Florida Department of Agriculture and Consumer Services) for providing a reference collection for the identification of Aphodiinae specimens. We thank the Salisbury University, Department of Biological Sciences for support and funding to complete this project. Funding was also provided by the Salisbury University Guerrieri Undergraduate Research Endowment, the Henson School of Science and Technology, and the Salisbury University Undergraduate Student Academic Research Award.

\section{Literature Cited}

Blume, R.R. 1981. Glaphyrocanthon viridis (Beauvois): Description of larva and notes on biology. Coleopterists Bulletin 36:250-238.

Brofman, I. 2015. A plan for wildlife conservation in the $21^{\text {st }}$ century. The Maryland Natural Resource Magazine Spring 2015:10-11.

Brush, G.S. 2008. Historical land use, nitrogen, and coastal eutrophication: A paleoecological perspective. Estuaries and Coasts 32:18-28.

Brush, G.S., and W.B. Hilgartner. 2000. Paleoecology of submerged Acrophytes in the upper Chesapeake Bay. Ecological Monographs 70(4):645-667.

Colwell, R.K. 2013. EstimateS, Version 9.1: Statistical estimation of species richness and shared species from samples. Available online at http://viceroy.eeb.uconn.edu/estimates/index.html. Accessed 14 March 2017.

Davis, A.J., J.D. Holloway, H. Huijbregts, J. Krikken, A.H. Kirk-Spriggs, and S.L. Sutton. 2001. Dung beetles as indicators of change in the forests of northern Borneo. Journal of Applied Ecology 38:593-616.

Edwards, J. 1981. A brief description of the geology of Maryland. Maryland Department of Natural Resources, Maryland Geological Survey. Available online at http://www.mgs. md.gov/geology/geology_of_maryland.html. Accessed 14 March 2017.

Feer, F., and Y. Hingrat. 2005. Effects of forest fragmentation on a dung beetle community in French Guiana. Conservation Biology 19(4):1103-1112.

Fincher, G.T., T.B. Stewart, and R. Davis. 1970. Attraction of coprophagous beetles to feces of various animals. The Journal of Parasitology 56:378-383.

Gardner, T.A., J. Barlow, I.S. Araujo, T.C. Ávila-Pires, A.B. Bonaldo, J.E. Costa, M.C. Esposito, L.V. Ferreira, J. Hawes, M.I.M. Hernandez, M.S. Hoogmoed, R.N. Leite, N.F. Lo-Man-Hung, J.R. Malcolm, M.B. Martins, L.A.M. Mestre, R. Miranda-Santos, W.L. Overal, L. Parry, S.L. Peters, M.A. Ribeiro-Junior, M.N.F. da Silva, C.D.S. Motta, and C.A. Peres. 2008. The cost-effectiveness of biodiversity surveys in tropical forests. Ecological Letters 11:139-150.

Gotelli, N.J., and R.K. Colwell. 2001. Quantifying biodiversity: Procedures and pitfalls in the measurement and comparison of species richness. Ecology Letters 4(4):379-391. 
Hanski, I. 1980. Movement patterns in dung beetles and in the dung fly. Animal Behaviour 28(3):953-964.

Hanski, I., and Y. Cambefort. 1991. Dung Beetle Ecology. Princeton University Press, Princeton, NJ. 514 pp.

Harpootlian, P.J., J.C. Morse, and A.G. Wheeler. 2001. Scarab Beetles (Coleoptera: Scarabaeidae) of South Carolina. Volume 2. Clemson University Public Service Activities, Clemson, SC. 157 pp.

Howden, H. 1955. The biology and taxonomy of North American beetles of the subfamily Geotrupinae with revisions of the genera Bolbocerosoma, Eucanthus, Geotrupes, and Peltotrupes (Scarabaeidae). Proceedings of the United States National Museum 104:151-319.

Howden, H.F., and O.L. Cartwright. 1963. Scarab beetles of the genus Onthophagus Latreille North of Mexico (Coleoptera: Scarabaeidae). Proceedings of the United States National Museum 114:1-35.

Howden, H.F., and V.G. Nealis. 1975. Effects of clearing in a tropical rain forest on the composition of the coprophagous scarab beetle fauna (Coleoptera). Biotropica 7(2):77-83.

Kays, J. 1995. Maryland's forests: Past, present, and future. Cooperative Extension Service, University of Maryland at College Park, University of Maryland Eastern Shore, Princess Anne, MD. 8 pp.

Larsen, T.H. 2007. Dung beetles: A rapid biological assessment of the Lely and Nassau Plateaus, Suriname. RAP Bulletin of Biological Assessment 43:91-103.

Larsen, T.H. 2011. Dung beetles: A rapid biological assessment of the Kwamalasamutu region, southwestern Suriname. RAP Bulletin of Biological Assessment 63:91-103.

Larsen T.H., and A. Forsyth. 2005. Trap spacing and transect design for dung beetle biodiversity studies. Biotropica 37:322-325.

Maryland Department of Natural Resources (MDNR). 2015. Sustainable forest-management plan for Chesapeake forest lands. Available online at http://dnr.maryland.gov/ forests/Pages/chesapeakeforestlands.aspx. Accessed 14 March 2017.

MDNR. 2017. Janes Island State Park. Available online at http://dnr2.maryland.gov/publiclands/Pages/eastern/janesisland.aspx. Accessed 14 March 2017.

Maryland State Wildlife Action Plan (MSWAP). 2015. Available online at http://dnr. maryland.gov/wildlife/Pages/plants_wildlife/SWAP_Submission.aspx. Accessed 14 March 2017.

Maryland's Strategic Forest Lands Assessment (MSFLA). 2003. Available online at http:// dnr.maryland.gov/forests/Documents/sfla_report.pdf. Accessed 10 September 2017.

McGeoch, M.A., B.J. Van Rensburg, and A. Botes. 2002. The verification and application of bioindicators: A case study of dung beetles in a savanna ecosystem. Journal of Applied Ecology 39(4):661-672.

Menéndez, R., and D. Gutiérrez. 1999. Heterotrophic succession within dung-inhabiting beetle communities in northern Spain. Acta Oecologica 20(5):527-535.

Nealis, V.G. 1977. Habitat associations and community analysis of South Texas dung beetles (Coleoptera: Scarabaeinae). Canadian Journal of Zoology 55(1):138-147.

Nichols, E.S., and T.A. Gardner. 2011. Dung beetles as a candidate study-taxon in applied biodiversity-conservation research. Pp. 267-291, In L. Simmons, and J. Ridsdill-Smith (Eds.). Ecology and Evolution of Dung Beetles. Blackwell Publishing Ltd., Hoboken, NJ. 368 pp.

Nichols, E., S. Spector, J. Louzada, T. Larsen, S. Amezquita, and M.E. Favila. 2008. Ecological functions and ecosystem services provided by Scarabaeinae dung beetles. Biological Conservation 141:146-1474. 
Nichols, E., T.A. Gardner, C.A. Peres, S. Spector, and the Scarabaeinae Research Network. 2009. Co-declining mammals and dung beetles: An impeding ecological cascade. Oikos 118:481-487.

Payne, J.A., and E.W. King. 1969. Coleoptera associated with pig carrion. Entomologists Monthly Magazine 105:224-232.

Price, D.L. 2004. Species diversity and seasonal abundance of scarabaeoid dung beetles (Coleoptera: Scarabaeidae, Geotrupidae, and Trogidae) attracted to cow dung in central New Jersey. Journal of the New York Entomological Society 112(4):334-347.

Price, D.L., L.M. Brenneman, and R.E. Johnston. 2012. Dung beetle (Coleoptera: Scarabaeidae and Geotrupidae) communities of eastern Maryland. Proceedings of the Entomological Society of Washington 114(1):142-151.

Ratcliffe, B.C., and M.J. Paulsen. 2008. The scarabaeoid beetles of Nebraska (Coleoptera: Scarabaeoidea). Bulletin of University of Nebraska State Museum Bulletin 22:1-570.

Reed, H.B., Jr. 1958. A study of dog carcass communities in Tennessee, with special reference to the insects. American Midland Naturalist 59(1):213-245.

Rentz, E., and D.L. Price. 2016. Species diversity and succession of dung beetles to horse dung on Assateague Island. Coleopterists Bulletin 70(1):95-104.

Sabu, T.K., K.V. Vinod, and P.J. Vineesh. 2007. Succession of dung beetles (Scarabaeinae: Coleoptera) in the dung pats of Gaur, Bos gaurus H. Smith (Artiodactyla: Bovidae), from the moist deciduous forests of southern Western Ghats. Biosystematica 1(1):59-69.

Scott, J. 1991. Between Ocean and Bay: A Natural History of Delmarva. Tidewater Publishers, Centreville, MD. 221 pp.

Sipple, W.S. 1994. A natural history of the Pocomoke river watershed with special reference to its wetlands. Privately printed. $61 \mathrm{pp}$.

Spector, S. 2006. Scarabaeinae dung beetles (Coleoptera: Scarabaeidae: Scarabaeinae): An invertebrate focal taxon for biodiversity research and conservation. Coleopterists Bulletin 60:71-83.

Staines, C.L. 1984. An annotated checklist of the Scarabaeoidea (Coleoptera) of Maryland. Maryland Entomologist 2(4):79-89.

Walker, T.J. 1957. Ecological studies of the arthropods associated with certain decaying materials in 4 habitats. Ecology 38:262-276.

Whipple, S.D. 2011. Dung beetle ecology: Habitat and food preference, hypoxia tolerance, and genetic variation. Ph.D. Dissertation. University of Nebraska Lincoln, NE.

Woodruff, R.M. 1973. The scarab beetles of Florida (Coleoptera: Scarabaeidae). Part I. The Laprosticti (Subfamilies: Scarabaeinae, Aphodiinae, Hybosorinae, Ochodaeinae, Geotrupinae, Acanthocerinae). Arthropods of Florida and Neighboring Land Areas 8:1-220.

Young, O.P. 1984. Utilization of dead insects on the soil surface in row-crop situations. Environmental Entomology 13:1346-1351.

Young, O.P. 2007. Laboratory studies on the feeding behavior of the putative dung beetle Ateuchus histeroides (Coleoptera: Scarabaeidae). Journal of the New York Entomological Society 114(3):157-169. 